\title{
Increased Cellular Expression of Matrix Proteins That Regulate Mineralization Is Associated with Calcification of Native Human and Porcine Xenograft Bioprosthetic Heart Valves
}

\author{
S.S. Srivatsa, ${ }^{\star}$ P.J. Harrity, ${ }^{\|}$P.B. Maercklein, ${ }^{\ddagger}$ L. Kleppe, ${ }^{\ddagger}$ J. Veinot, ${ }^{\|}$W.D. Edwards, ${ }^{\|}$C.M. Johnson, ${ }^{\S}$ and L.A. Fitzpatrick ${ }^{\ddagger}$ \\ Divisions of $*$ Cardiology and ${ }^{\ddagger}$ Endocrinology, Department of Internal Medicine, ${ }^{\S}$ Department of Pediatrics, and ${ }^{\|}$Department of \\ Pathology, Mayo Clinic and Mayo Foundation, Rochester, Minnesota 55905
}

\begin{abstract}
Dystrophic mineralization remains the leading cause of stenotic or regurgitant failure in native human and porcine bioprosthetic heart valves. We hypothesized that cellular expression of noncollagenous matrix proteins (osteopontin, osteocalcin, and osteonectin) that regulate skeletal mineralization may orchestrate valvular calcification.

Porcine bioprosthetic heart valves and native human heart valves obtained during replacement surgery were analyzed for cells, matrix proteins that regulate mineralization, and vessels.

Cell accumulation and calcification were correlated for both valve types (rho $=0.75, P=0.01$, native; rho $=0.42, P=$ 0.08 , bioprosthetic). Osteopontin expression correlated with cell accumulation (rho $=0.58, P=0.04$ ) and calcification (rho $=0.52, P=0.06$ ) for bioprosthetic valves. Osteocalcin expression correlated with calcification (rho $=0.77, P=$ 0.04 ) and cell accumulation (rho $=0.69, P=0.07$ ) in native valves. Comparisons of calcified versus noncalcified native and bioprosthetic valves for averaged total matrix protein mRNA signal score revealed increased noncollagenous proteins mRNA levels in calcified valves $(P=0.07$, group I vs. group II; $P=0.02$, group III vs. group IV). When stratified according to positive versus negative mRNA signal status, both calcified bioprosthetic valves $(P=0.03)$ and calcified native valves $(P=0.01)$ were significantly more positive for noncollagenous proteins mRNA than their noncalcified counterparts.

Local cell-associated expression of proteins regulating mineralization suggests a highly coordinated mechanism of bioprosthetic and native valve calcification analogous to physiologic bone mineralization. Modulation of cellular infiltration or cellular expression of matrix proteins that regulate mineralization, may offer an effective therapeutic approach to the prevention of valve failure secondary to calcification. (J. Clin. Invest. 1997. 99:996-1009.) Key words: noncollagenous matrix proteins - calcification • heart valves • in situ hybridization • osteopontin
\end{abstract}

This work was presented, in part, as a Key Contribution Poster Session of the American College of Cardiology, 44th Annual Scientific Session, 1995. Copyright Mayo Foundation 1996.

Address correspondence to L.A. Fitzpatrick, M.D., 5-164 West Joseph Building, Mayo Clinic and Mayo Foundation, 200 First St. SW, Rochester, MN 55905. Phone: 507-255-6663; FAX: 507-255-4828.

Received for publication 28 March 1996 and accepted for publication 25 November 1996.

The Journal of Clinical Investigation

Volume 99, Number 5, March 1997, 996-1009

\section{Introduction}

Dystrophic mineralization of both native human and porcine xenograft bioprosthetic heart valves remains a recalcitrant cause of native valve stenosis and degenerative prosthetic valve failure $(1,2)$. In spite of the development of artificial heart valves and diverse pharmacologic anticalcification strategies, prosthetic valvular calcification and secondary failure remain significant hurdles to successful long-term function. The mechanism of valvular calcification remains poorly understood and elusive to therapy. Calcific aortic stenosis may result from several causes including congenitally bicuspid aortic valves that undergo degeneration and dystrophic calcification (3), postinflammatory commissural fusion and fibrocalcific cusp thickening due to rheumatic fever (4), or degenerative "senile" calcific stenosis of a tricuspid aortic valve $(5,6)$. Calcification is also the principal cause of clinical failure of glutaraldehydetreated porcine aortic valve bioprostheses resulting in either calcific stenosis or cusp tearing and incompetence (7-9). Failure due to pathologic calcification has significantly limited the functional lifetime of all bioprostheses. These include valved human aortic homografts, bovine pericardial xenograft valves, autografts fabricated from dura mater and fascia lata, and synthetic trileaflet polymeric prostheses (10-15). The ubiquitous calcification of native human tissue, porcine tissue, and synthetic biomaterials argues for a universal calcification mechanism independent of substrate which is susceptible to modulation by host and biomechanical factors.

Calcification has been described as pathologic or "abnormal" when occurring in functional soft tissues, and physiologic or "normal" when occurring in skeletal tissues. Pathologic calcification of necrotic, damaged or chemically altered tissues in normocalcemic hosts has been termed "dystrophic" $(16,17)$. Dystrophic calcification occurs in numerous cardiovascular conditions including atherosclerosis, valvular stenosis, and reperfused ischemic myocardium. Dystrophic calcification has been characterized as haphazard or unregulated and is proposed to be an undesired but common feature of degenerative or inflammatory tissue changes throughout the body. Recent experimental evidence has suggested that active regulation of dystrophic atherosclerotic calcification involves expression of noncollagenous matrix proteins responsible for the regulation of skeletal mineralization (18-24). Pathologic calcification and physiologic mineralization of skeletal and dental tissues share important common features such as cell- and collagen-associated crystal deposition and nidus formation within matrix vesicles of cell membranes (25). Tissue mineralization involves a complex interaction of cells and regulatory extracellular matrix components. Noncollagenous matrix proteins are critical to the establishment and regulation of mineralization, since type I collagen dissociated from noncollagenous matrix pro- 
teins is incapable of supporting hydroxyapatite formation (20, $21,26,27)$.

The noncollagenous matrix proteins investigated in this study are expressed at specific stages of bone development and form the framework for calcification in skeletal tissue (for review see reference 28 ). In addition to mineral-inducing properties, these matrix proteins regulate bone cell migration, differentiation, attachment, and function $(21,27)$. The presence of these proteins within heterotopic ossification sites such as pressure sores in paraplegic patients has been demonstrated (29). We hypothesized that cell-mediated expression of noncollagenous matrix proteins such as osteopontin, osteocalcin, and osteonectin may be associated with the pathologic mineralization and remodeling of extraskeletal tissues such as heart valves. In this study, we demonstrate the increased cellular expression of these noncollagenous matrix proteins in close association with valvular mineralization and suggest a common mechanism for the calcification of native human and porcine bioprosthetic heart valves.

\section{Methods}

18 porcine xenograft bioprostheses and 13 native human heart valves were studied. These valves were removed at surgery from adult patients, fixed in $10 \%$ neutral phosphate-buffered formalin, and sectioned craniocaudally through the midportions of the coronary cusps.
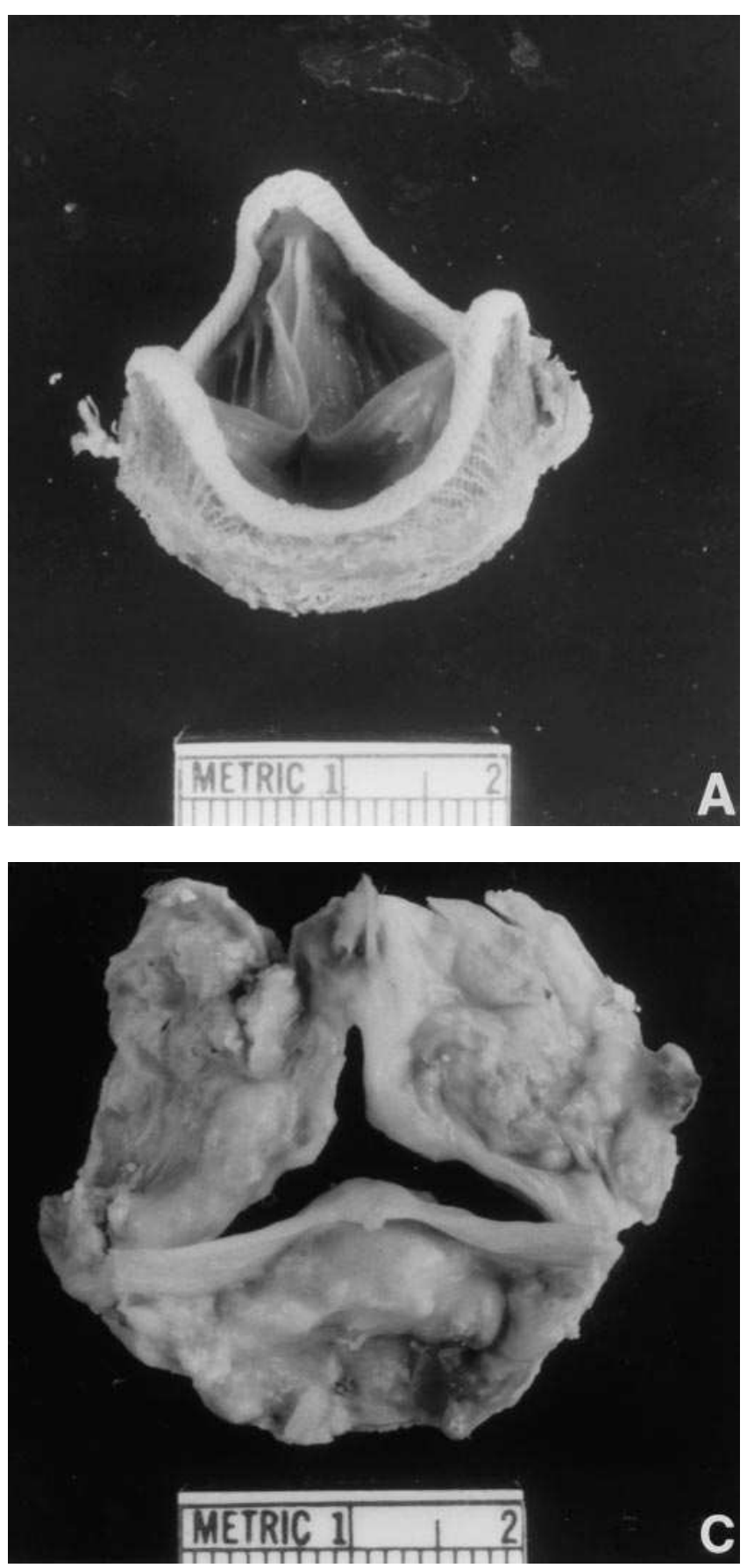

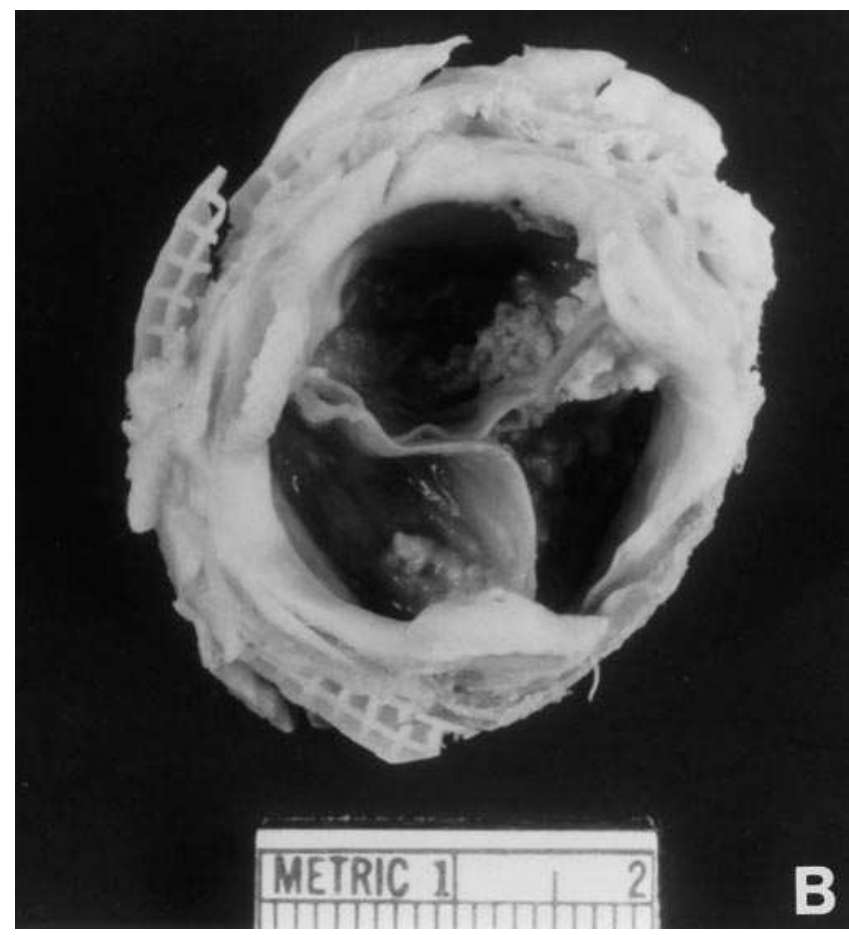

Figure 1. (A) Gross pathology of stented porcine bioprosthetic aortic valve demonstrating cusp tear without gross calcification, resulting in valvular incompetence (group I). (B) Gross pathology of stented porcine bioprosthetic aortic valve demonstrating calcific deposits at the free edges and commissures causing stenosis (group II). (C) Gross pathology of native tricuspid aortic valve showing extensive cuspal and commissural calcific deposits causing stenosis (group IV). 
Paraffin-embedded tissue was sectioned at 5- $\mu \mathrm{m}$ intervals and placed on poly-L-lysine-coated slides. Multiple sequential sections were obtained across each valve cusp at 2-mm intervals from commissure to commissure across the cuspal center. Presence of calcium was estimated by visual inspection for purposes of subclassification. For quantitative analysis, calcium salts were identified histologically with both von Kossa's and Goldner's-Masson-Trichrome reagents. Valves were divided into four groups: porcine bioprosthetic valves with degeneration but no calcification that were removed because of aortic or mitral incompetence ( $n=8$, group I, Fig. $1 A)$; porcine bioprosthetic valves with gross calcification but no degeneration removed due to valvular stenosis $(n=10$, group II, Fig. $1 B)$; native human heart valves without calcification removed due to degenerative valvular incompetence ( $n=5$, group III); and native human heart valves with gross calcification removed due to symptomatic valvular stenosis $(n=8$, group IV, Fig. $1 C$ ). One patient in group III had healed infective endocarditis. The prosthetic tissue valves (Hancock and Carpentier-Edwards porcine valve bioprostheses) studied are the two most commonly used flexible stent-mounted porcine aortic valve bioprostheses. They are composed of glutaraldehyde-preserved pig aortic valve leaflets mounted on a supporting frame. The average postoperative interval of the porcine xenograft valves explanted in groups I and II was $10.0 \pm 1.9$ and $9.9 \pm 0.9 \mathrm{yr}$, respectively. The average age of the patients at valve explant in groups III and IV was $76.0 \pm 4.5$ and $72.5 \pm 2.6 \mathrm{yr}$, respectively. Valve sections were routinely processed for immunohistochemistry, hematoxylin and eosin, Lawson's elastic van Gieson, von Kossa, and Goldner's-Masson-Trichrome stains. Separate contiguous sections were used for in situ hybridization (ISH) ${ }^{1}$ analysis.

\section{Immunohistology}

The following antibodies were used (DAKO, Carpinteria, CA): antiCD68 (PGM1) mouse monoclonal IgG 3 against human monocytemacrophage antigen; anti-CD45 (UCHL1), mouse monoclonal IgG $2 \mathrm{a}$ against human $\mathrm{T}$ cell antigen; anti- $\alpha$ smooth muscle actin (1A4), mouse IgG 2a monoclonal against $\alpha$-smooth muscle actin; anti-human von Willebrand factor, rabbit polyclonal IgG against human von Willebrand factor, a constitutively expressed marker of vascular endothelial cells.

The following antibodies to matrix proteins were used: anti-human osteopontin, rabbit polyclonal IgG antibody (LF-7); anti-bovine osteonectin, rabbit polyclonal $\mathrm{IgG}$ antibody cross-reactive to human (LF-BON-II); anti-human osteocalcin, rabbit polyclonal IgG antibody (LF-32). All antisera cross-reacted with porcine tissue. These antisera were generously provided by Dr. Larry Fisher (National Institute of Dental Research, National Institutes of Health, Bethesda, MD) (30).

Tissue sections were deparaffinized in xylene and rehydrated in ascending alcohols. After digestion with $0.05 \%$ trypsin in phosphatebuffered saline for $10 \mathrm{~min}$, sections were rinsed in Tris-buffered saline (TBS) with $0.2 \%$ Triton X-100. Sections were blocked with TBS containing $0.3 \%$ casein and $10 \%$ normal goat serum and stained using a Vectastain Elite ABC kit (Vector Laboratories, Burlingame, CA) according to the manufacturer's recommendations with the following modifications. All steps were carried out at room temperature and followed by a 30 -min wash with TBS containing $1 \%$ normal goat serum. Primary antibodies were applied after blocking at the appropriate concentration (determined by appropriate serial dilutions) and incubated overnight at $4^{\circ} \mathrm{C}$. Secondary antibody (biotinylated antiprimary antibody species) was applied at a 1:100 dilution. Endogenous peroxidase activity was inhibited with absolute methanol and $3 \%$ hydrogen peroxide. Peroxidase-conjugated avidin-biotin complex was allowed to react with secondary antibody for $30 \mathrm{~min}$, and antibody

1. Abbreviations used in this paper: hpf, high power field; ISH, in situ hybridization. complexes were visualized after addition of $0.01 \%$ diaminobenzidine or 3-amino-9-ethylcarbazole chromogen and $0.01 \% \mathrm{H}_{2} \mathrm{O}_{2}$ in Tris, $\mathrm{pH}$ 7.2, for 4-6 min. Finally, sections were rinsed in tap water, dehydrated in ascending alcohols, cleared with xylene, and mounted on glass slides with coverslips using Eukitt ${ }^{\mathrm{TM}}$ mounting medium (Calibrated Instruments, Inc., Ardsley, NY) or mounted directly with aqueous mounting medium $(27,29)$. Control sections were stained using isotype specific normal rabbit or mouse serum at the same concentration as the primary antibody. Known positive and negative human and porcine tissue controls were incorporated in each experiment for each antibody used.

Negative controls were also obtained by staining normal human spleen, thymus, and lymph node sections with the same primary antibodies to osteocalcin (LF-32), osteopontin (LF-7), and osteonectin (LF-BON-II) at dilutions used to stain the native and bioprosthetic heart valves. No osteopontin, osteocalcin, or osteonectin was detected in these tissues (data not shown).

\section{Histopathology}

Partial demineralization of valve tissue was necessary before formalin fixation to allow microtome sectioning. All valves were fixed for $6 \mathrm{~h}$ in $10 \%$ neutral buffered formalin and fixed for $16 \mathrm{~h}$ in a solution of $88 \%$ formic acid and $10 \%$ formalin before sectioning. These methodologic differences may explain some of the variation in matrix protein and calcium content both within and among valve groups (31) although all valves underwent identical fixation and processing. All slides were reviewed by two independent observers including an experienced cardiac histopathologist. 5- $\mu \mathrm{m}$-thick formalin-fixed paraffin embedded sections were stained with hematoxylin and eosin and Lawson's elastic van Gieson for routine histology. Immunostaining for specific tissue components was compared with the findings of routine histology. Serial sections across each valve cusp were studied as noted above. Each valve cusp section was divided into thirds from the base to the top. The area of maximum cell density in each third of the leaflet was ordinarily graded using the following scoring system: inflammatory cells: $1=\leq 10$ cell per high power field (hpf), $2=10-25$ cells/hpf, $3=25-50$ cells/hpf, $4=50-100$ cells $/ \mathrm{hpf}, 5=\geq 100$ cells $/$ hpf; calcium: $1=\leq 50 \%$ cusp area and $\leq 50 \%$ cusp thickness, $2=\geq$ $50 \%$ cusp area and $\geq 50 \%$ cusp thickness; vessels: $0=\leq 5 / \mathrm{hpf}, 1=$ $5-10 / \mathrm{hpf}, 2=10-15 / \mathrm{hpf}, 3=>15 / \mathrm{hpf}$. High power field was defined as $150 \times$ magnification. Scores were calculated for all sequential sections across each valve cusp and averaged across all sections to obtain an overall score for each patient valve. Data were averaged across all patients within each valve group for individual histologic variables. Presence of calcium deposits was determined using both von Kossa and Goldner's-Masson-Trichrome stains.

\section{ISH}

Target mRNA sequences for matrix proteins were selected from the known DNA sequences encoding these proteins obtained via the GenBank database. Synthetic DNA probes were constructed and purified using oligonucleotide purification cartridges (Applied Biosystems, Foster City, CA). The following probes were synthesized: osteopontin: antisense probe synthesized as a 40-bp synthetic DNA oligonucleotide complementary to the osteopontin mRNA sequence starting at position 1173: 5' GAA GCT TTT AGT TTA CAG GGA GTT TCC ATG AAG CCA CAA A 3'; osteonectin: antisense 50-bp DNA oligomer complementary to the osteonectin mRNA sequence starting at position 1232: 5' TGT GTT TAA GGC AGA GCC CAG CAG ATC CGT GTC CAC CCA TGT GCC AAT AA 3'; and osteocalcin: antisense 50-bp oligomer complementary to the osteocalcin mRNA sequence starting at position 237: 5' GAA AGC CGA TGT GGT CAG CCA ACT CGT CAC AGT CCG GAT TGA GCT CAC AC 3 '.

Complementary sense probes for all three sequences were used as controls. ${ }^{35} \mathrm{~S}-[\mathrm{AMP}]^{\mathrm{n}}$-Labeled single-stranded cDNA probes for mRNA were prepared using terminal deoxynucleotidyl transferase and $\left[\alpha{ }^{35}\right.$ S $]$ dATP provided as an NEP100 labeling kit (Dupont, Bos- 
Table I. Valve Histopathology Compared by Morphologic Valve Categories

\begin{tabular}{llll}
\hline & \multicolumn{1}{c}{ Calcium } & \multicolumn{1}{c}{ Cells } & \multicolumn{1}{c}{ Vessels } \\
\hline I vs. II & 6.50 vs. $11.41^{*}$ & 8.29 vs. 10.27 & 9.5 vs. 9.5 \\
III vs. IV & 5.20 vs. 8.13 & 5.60 vs. 7.88 & 5.90 vs. 7.69 \\
I vs. III & 5.64 vs. 7.70 & 4.71 vs. $9.00^{\ddagger}$ & 5.50 vs. 7.90 \\
II vs. IV & 9.86 vs. 10.19 & 6.82 vs. $14.38^{\S}$ & 7.50 vs. 13.44
\end{tabular}

Data represent mean rank values for each histologic variable according to valve group. Valve groups: $\mathrm{I}=$ Bioprosthetic non- $\mathrm{Ca}^{2+}, \mathrm{II}=$ Bioprosthetic $\mathrm{Ca}^{2+}$, III $=$ Native non-Ca ${ }^{2+}$, and IV $=$ Native $\mathrm{Ca}^{2+}$. Significance determined by Mann-Whitney U test: $* P=0.05$, I vs. II; $\| P=0.02$, II vs. IV $;{ }^{\S} P=0.003$, II vs. IV $;{ }^{\ddagger} P=0.04$, I vs. III.

ton, MA). ${ }^{35} \mathrm{~S}$-Labeled probes were used at a specific activity of $1 \times$ $10^{6} \mathrm{cpm} / \mu \mathrm{l}$. Tissue sections were deparaffinized in xylene, cleared in descending alcohols, and rehydrated. Permeabilization with $0.05 \%$ Triton X-100 and deproteinization with $0.2 \mathrm{~N} \mathrm{HCl}$ were followed by proteinase $\mathrm{K}$ digestion $(10 \mu \mathrm{g} / \mathrm{ml}$ in $50 \mathrm{mM}$ EDTA, $0.1 \mathrm{M}$ Tris, $\mathrm{pH}$ 8.0 , for $30 \mathrm{~min}$ at $37^{\circ} \mathrm{C}$ ). Acetylation with $0.25 \%$ acetic anhydride in $0.1 \mathrm{M}$ triethanolamine was used to reduce nonspecific probe binding, followed by washing in $2 \times$ SSC (saline sodium citrate composed of $0.3 \mathrm{M} \mathrm{NaCl}, 0.3 \mathrm{M}$ trisodium citrate, $\mathrm{pH} 7.0$ ) and dehydration in ascending alcohols. $70 \mu \mathrm{l}$ of hybridization solution (50\% deionized formamide, $10 \mathrm{mM}$ DTT, $1 \mathrm{mM}$ EDTA, $10 \mathrm{mM}$ Tris-HCl, pH 8.0, $0.3 \mathrm{M}$ $\mathrm{NaCl}, 1 \mathrm{mg} / \mathrm{ml}$ herring sperm DNA, $10 \mathrm{mg} / \mathrm{ml}$ yeast tRNA, 2\% Denhardt's solution, $10 \%$ dextran sulphate) containing $\sim 5 \times 10^{4} \mathrm{cpm}$ of ${ }^{35} \mathrm{~S}$-labeled probe was applied to pretreated sections and hybridized overnight, covered by acetylated coverslips at varying optimized hybridization temperatures based on the percentage of guanosine cytosine content of the probe and formamide concentrations.

After hybridization, coverslips were removed and sections were gradually desalted using decreasing concentrations of SSC $(4 \times$ to $0.5 \times$ ) containing $1 \mathrm{mM}$ DTT as antioxidant. Slides were then uniformly coated with Kodak NTB-2 emulsion, dried, and exposed for $3 \mathrm{~d}$ at $4^{\circ} \mathrm{C}$. Development in Kodak D-19 developer was followed by fixation and counterstaining (equal parts Toluidine blue 1:50 and Giemsa 1:50). Controls for ISH included: $(a)$ sense DNA oligomers derived from the target mRNA sequence; $(b)$ pretreatment of tissue sections with RNAase before hybridization; (c) positive pig bone sections processed in a manner identical to the valve sections; and $(d)$ normal human and pig valves without overt degeneration or calcification.

ISH analysis. The total number of cells expressing ISH signal for each noncollagenous matrix protein was counted across all serial valve leaflet sections. Contiguous sections across each valve leaflet from commissure to commissure were used. The total number of cells positive for each matrix protein probe per valve slide (ISH score) was recorded for each individual probe (osteocalcin, osteonectin, or osteopontin). Each patient's valve was assigned a positive or negative ISH probe status for each matrix protein, with positive states defined as $>5$ cells positive for mRNA signal in any valve section. These criteria were derived by reference to ISH signal levels for osteocalcin, osteonectin, and osteopontin in normal human and porcine heart valves (data not shown). A mean ISH signal score for each probe was obtained by averaging across all patients within each valve group. Mean ISH signal score for each probe was compared according to gross morphologic calcification status of valve groups I-IV and microscopic calcium score using both Goldner's-Masson-Trichrome and von Kossa stains of valve sections to ascertain extent of calcification.

\section{Statistical analysis}

All continuous data are reported as mean \pm standard deviation. Group means of averaged scores for each mRNA detected were compared using two-tailed unpaired $t$ tests. The fractions of valves positive and negative for expression of each matrix protein mRNA were compared among valve groups using a two-tailed Fisher's exact test to analyze $2 \times 2$ contingency tables.

Ordinal ranking of data such as inflammatory cell density, vessel density, and calcification scores allowed comparison of histological data to each other using either Spearman's rank order correlation testing or comparison by Mann-Whitney $U$ test for nonparametric distribution data. Lastly, valves from all groups were divided into high and low calcium categories based on histologic calcium score. Native and bioprosthetic valves with high and low calcium scores were compared for the presence or absence of noncollagenous matrix

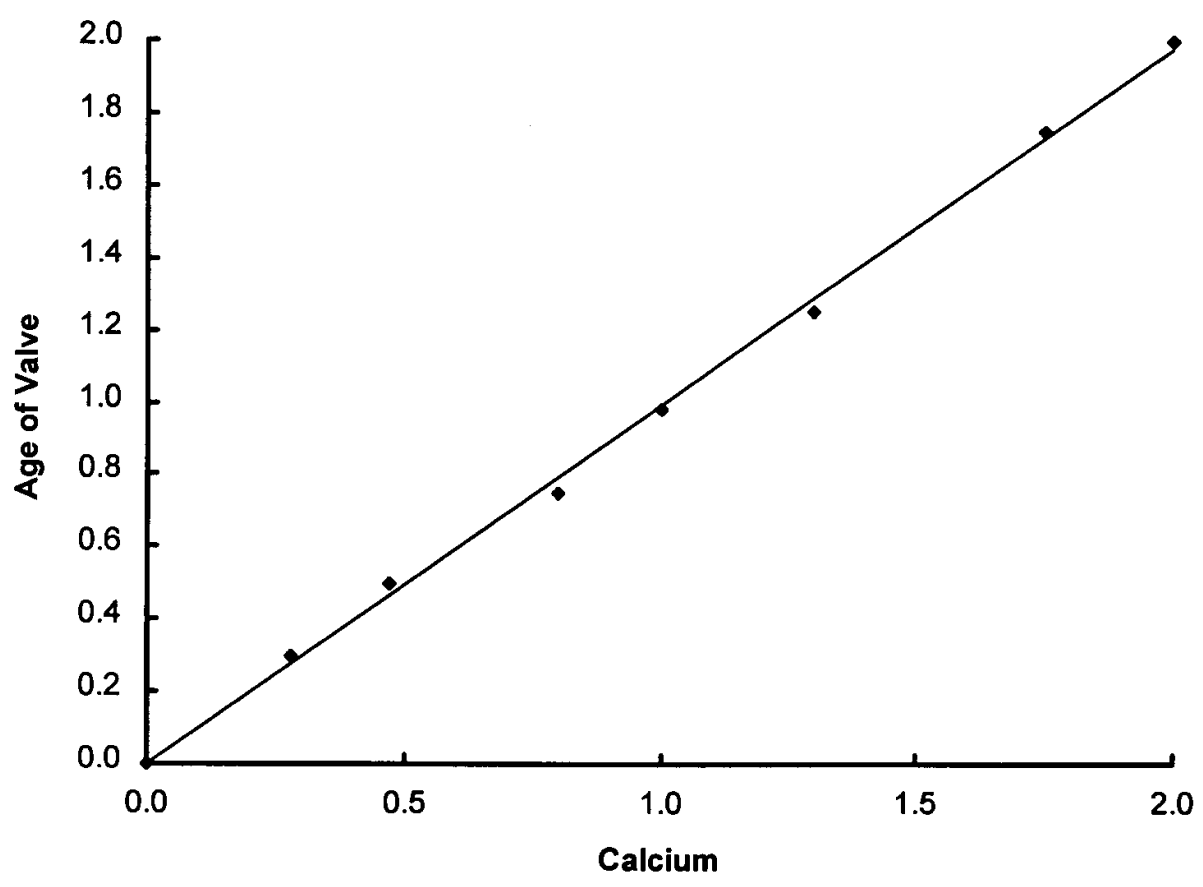

Figure 2. Spearman's rank order correlation of ordinal ranked calcium scores and valve ages for all bioprosthetic valves in groups I and II combined $(r=1.0$, $P=0.001)$. 


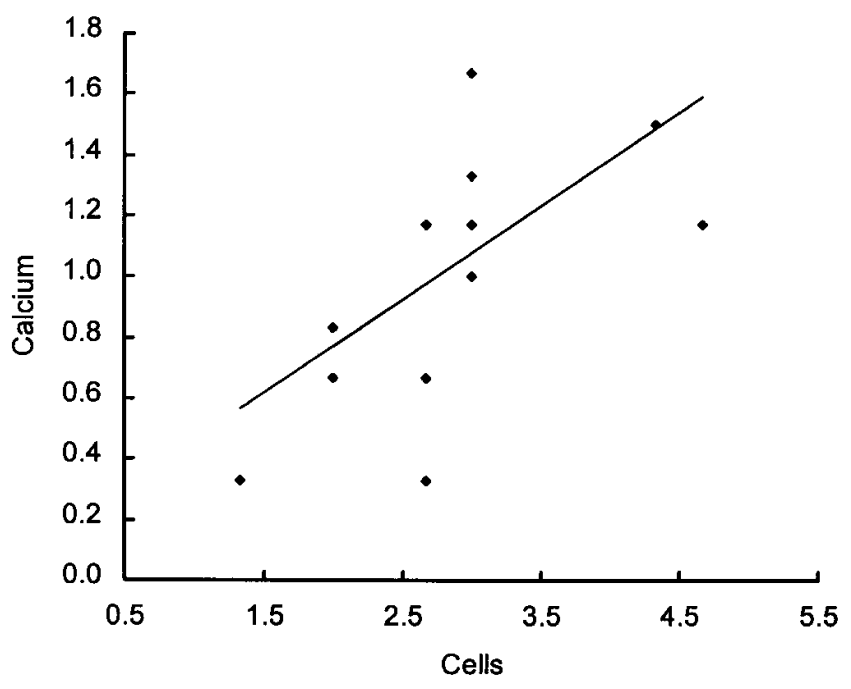

Figure 3. Spearman's rank order correlation of ordinal ranked cell and calcium scores for all native valves in groups III and IV combined $(r=0.75, P=0.03)$.

protein expression using a two-tailed Fisher's exact test to analyze $2 \times 2$ contingency tables.

\section{Results}

\section{Histopathology}

Valves were divided into calcified (groups II and IV) and uncalcified (groups I and III). Representative bioprosthetic and native valves are illustrated in Fig. 1. There were no significant differences in the ages of the valves among the bioprosthetic (120 \pm 66 mo, group I; $119 \pm 37$ mo, group II) or native valve groups (913 \pm 12 mo, group III; 870 \pm 87 mo, group IV). No significant differences in cellularity were observed among the cal-
Table II. Spearman Rank Correlation for Association of Matrix Protein Expression with Cellular Infiltration and Calcification of Heart Valves

\begin{tabular}{|c|c|c|c|c|}
\hline & \multicolumn{2}{|c|}{ Bioprosthetic } & \multicolumn{2}{|c|}{ Native } \\
\hline & Cell score & Calcium score & Cell score & Calcium score \\
\hline Osteopontin score & rho $=0.58$ & rho $=0.52$ & rho $=0.05$ & rho $=-0.33$ \\
\hline & $P=0.04^{*}$ & $P=0.06$ & $P=0.88$ & $P=0.40$ \\
\hline Osteonectin score & rho $=0.12$ & rho $=0.24$ & rho $=0.08$ & rho $=-0.30$ \\
\hline & $P=0.66$ & $P=0.38$ & $P=0.81$ & $P=0.40$ \\
\hline Osteocalcin score & $\begin{aligned} \text { rho } & =-0.19 \\
P & =0.51\end{aligned}$ & $\begin{aligned} \text { rho } & =0.03 \\
P & =0.92\end{aligned}$ & $\begin{aligned} \text { rho } & =0.69 \\
P & =0.07\end{aligned}$ & $\begin{aligned} \text { rho } & =0.77 \\
P & =0.04 *\end{aligned}$ \\
\hline
\end{tabular}

$* P \leq 0.05$ significance.

cified and noncalcified bioprosthetic groups or the calcified and noncalcified native valve groups (Table I). However, both calcified and noncalcified native heart valves were significantly more cellular than their bioprosthetic porcine counterparts ( $P=0.003$, II vs. IV; $P=0.04$, I vs. III). Calcified native valves (group IV) were significantly more vascular than calcified bioprosthetic valves $(P=0.02$, II vs. IV). There was no significant difference in calcium content between calcified native human and bioprosthetic valves. For bioprosthetic valves, a strong linear relationship was observed between calcium and the age of the valve (rho $=1.0, P<0.001$, Fig. 2 ). This relationship was not evident in the native valve groups (data not shown). For native valves, a strong correlation was evident between cell and calcium content (rho $=0.75, P=0.01$, Fig. 3 ). This relationship did not reach statistical significance in the bioprosthetic valve groups $(\mathrm{rho}=0.42, P=0.08)$.

Spearman's rank order correlation was used to test for association between matrix protein mRNA expression and either cell accumulation or valvular calcification. Results are summarized in Table II. For bioprosthetic valves, statistically

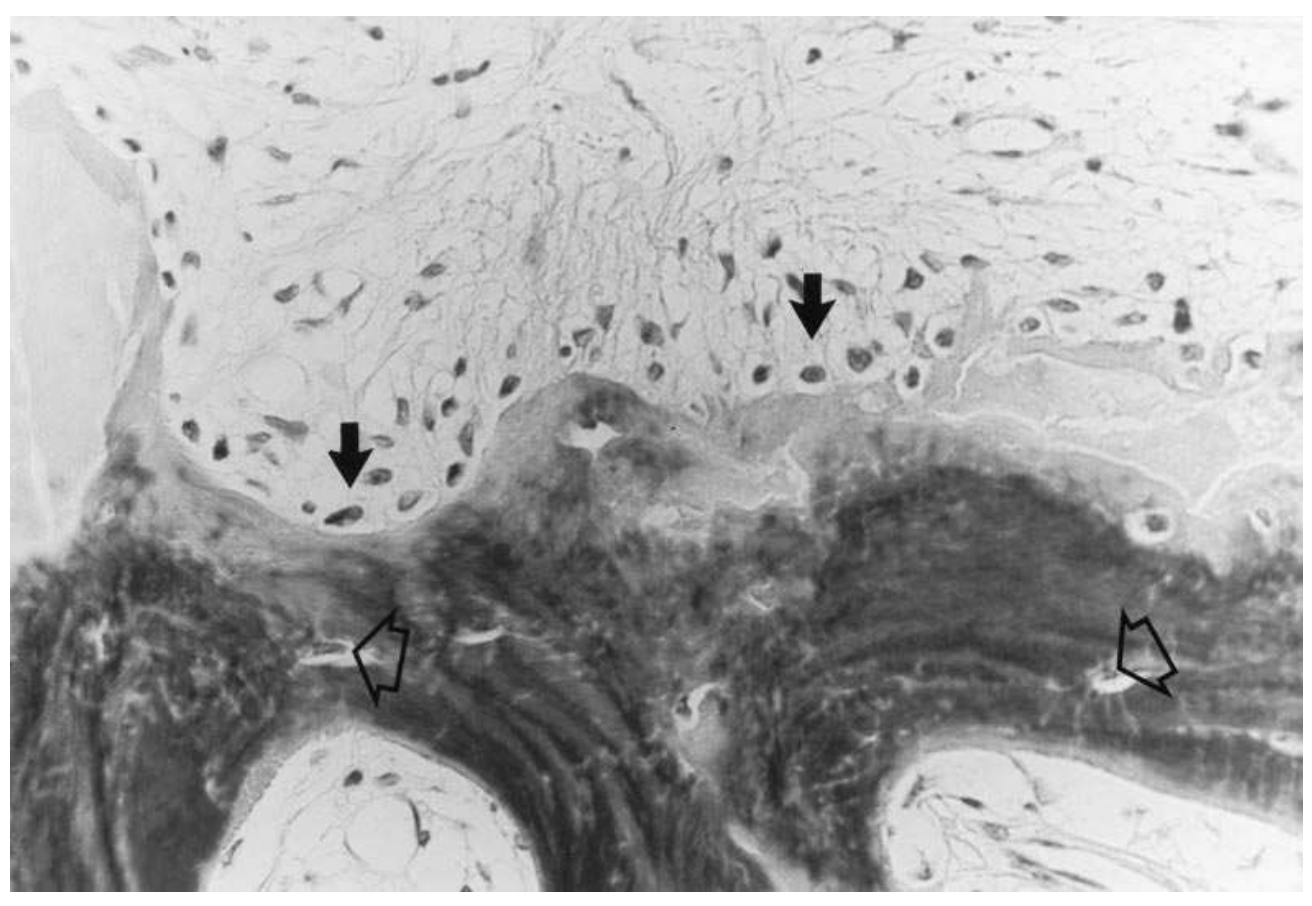

Figure 4. Goldner's-MassonTrichrome stain demonstrating region of woven bone within calcified native aortic valve. Note osteoblast-like cells adjacent to calcification front (closed arrows), bone containing mature osteocytes (open arrows), and surrounding neovascular stroma. 

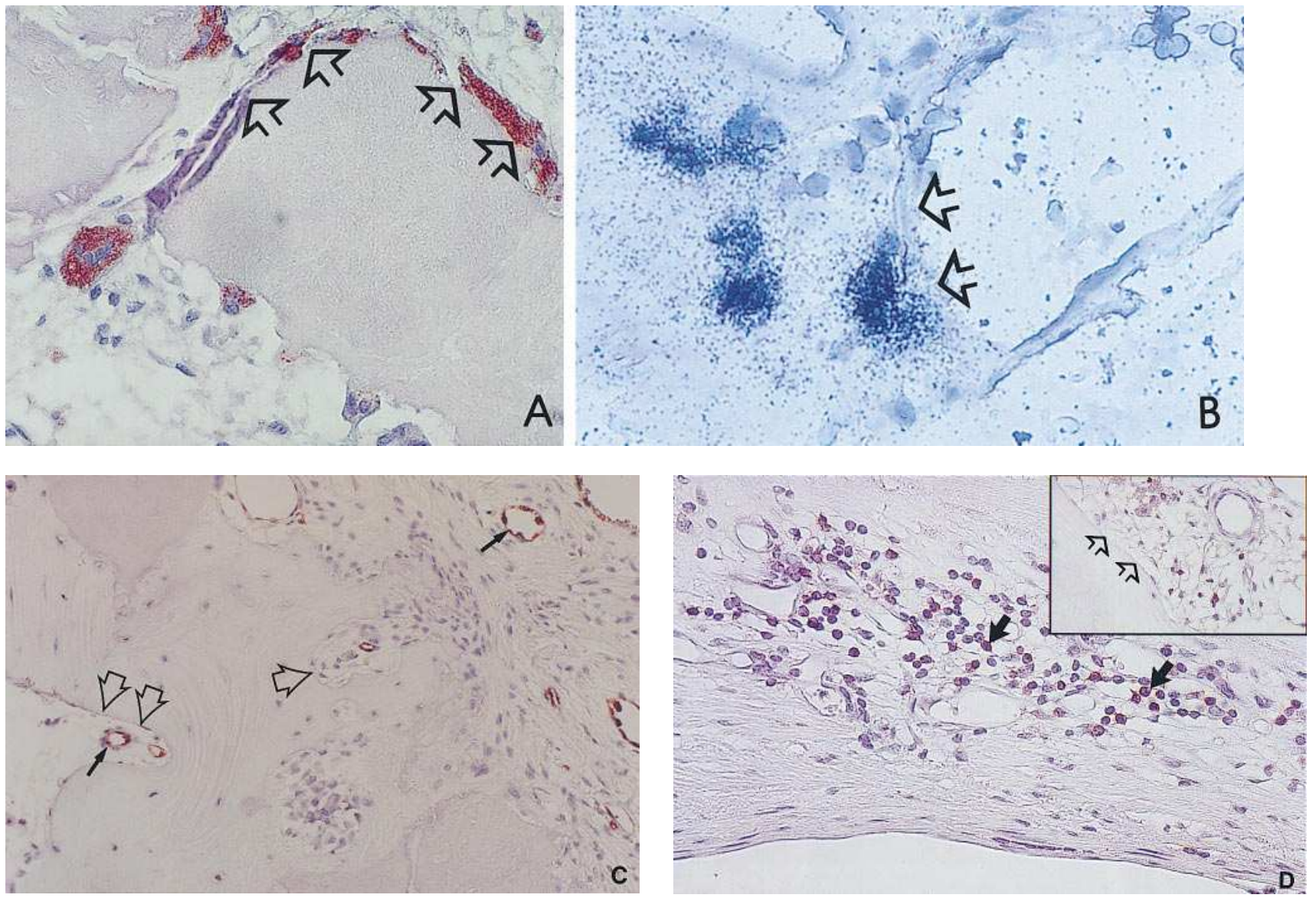

Figure 5. (A) Positive CD68 immunostaining for macrophages showing large multinucleated cells adherent to the calcification front (open arrows) of woven bone in a native human valve. (B) Section corresponding to $A$ showing ISH signal for osteocalcin mRNA overlying large mononuclear-macrophage cells adjacent to the calcification front (open arrows) of a native valve. (C) Immunostaining for von Willebrand factor constitutively expressed in endothelial cells demonstrates neovascular capillaries (solid arrows) adjacent to region of woven bone (open arrows) within a calcified native aortic valve. $(D)$ Fibrovascular stroma at edge of native aortic valve cusp demonstrating a mixed population of inflammatory cells including UCHL-1 positive T cells (closed arrows). (Inset) Low power photomicrograph of a valve area demonstrating UCHL-1 positive T cells adjacent to the calcification front (open arrows). (E) Immunostaining for $\alpha$-smooth muscle cell actin demonstrating $\alpha$-actin positive cells amidst a zone of extrinsic calcification (arrow) in a valve section. The calcified lesion is within an organizing thrombotic vegetation taken from a patient specimen with healed native infective endocarditis. The inset shows a high power photomicrograph of $\alpha$-actin positive cells.

significant association was found between cell infiltration and osteopontin expression $(\mathrm{rho}=0.58, P=0.04)$. The association between cell accumulation and calcification of bioprosthetic valves did not reach statistical significance (rho $=0.52, P=$ $0.06)$. In native valves, osteocalcin expression and valvular calcification were significantly associated (rho $=0.77, P=0.04)$. The association between cell accumulation and osteocalcin expression in native valves did not reach statistical significance (rho $=0.69, P=0.07)$.

\section{Immunohistology and special stains}

Native valves. Mineralization was demonstrated in each valve by staining with Goldner's-Masson-Trichrome (specific for hydroxyapatite) and von Kossa's stains (specific for phosphate). In one calcified bicuspid aortic valve, a region of actual woven bone was observed containing osteocyte-like cells and a mineralization front (Fig. 4). Numerous cells morphologically and immunocytochemically identical to macrophages were observed adherent to the calcification front of the mineralized 

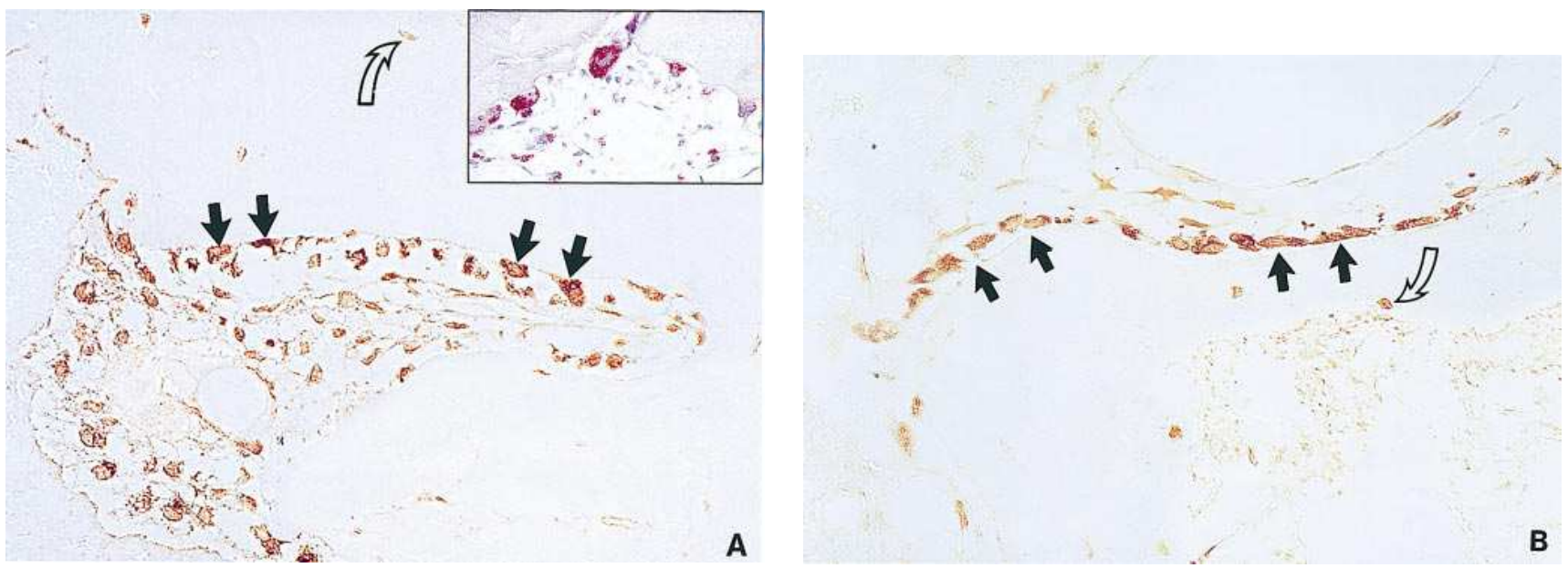

A

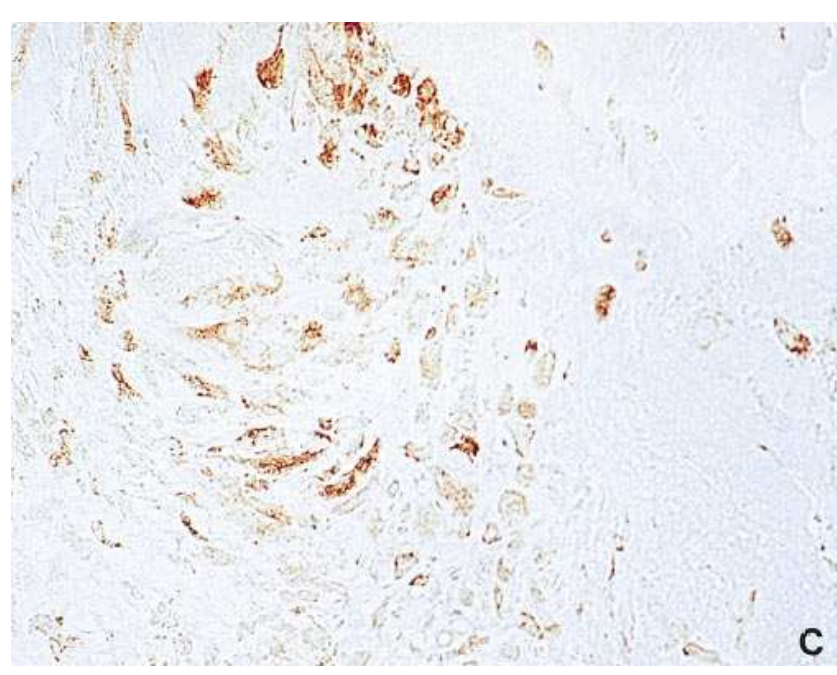

Figure 6. (A) Immunostaining for osteonectin protein localized to cells along the calcification front of woven bone observed within a calcified congenital bicuspid aortic valve (solid arrows). Osteocytes within the woven bone are also labeled (open arrow). The inset shows high power photomicrograph of CD68 positive immunostaining of large mononuclear and multinucleated cells adherent and adjacent to the calcification front of woven bone. (B) Immunostaining for osteocalcin protein within osteoblast-like cells at calcification front of woven bone (solid arrows), observed within a calcified congenital bicuspid aortic valve. Osteocytes within the woven bone are also labeled (open arrow). (C) Immunostaining for osteopontin showing labeling of mesenchymal cells within the fibrovascular stroma between zones of mineralization in a native human valve. $(D)$ Negative control representing lack of specific staining in the presence of nonimmune serum. Solid arrows indicate the edge of woven bone within a calcified native human valve.

area. Stains for differentiated osteoclasts (tartrate-resistant acid phosphatase, data not shown) failed to demonstrate positive reaction, suggesting that these cells were more likely to be macrophages than osteoclasts. CD68 positive macrophages were evident in the stroma around neovascular capillaries and along the calcification fronts of mineralizing zones (Fig. $5 \mathrm{~A}$ ).

Both senile and bicuspid native aortic valves with gross calcification demonstrated intense CD68 positive staining for macrophages at the calcification front of the mineralized valve zone (Fig. $5 \mathrm{~A}$ ). ISH signal for osteocalcin, osteonectin, and osteopontin was detected in the cells adjacent to this calcified area (Fig. $5 \mathrm{~B}$ ). Accompanying the extensive calcification of native valves, zones of valvular degeneration were observed containing increased capillary neovascularization as demonstrated by von Willebrand factor immunostaining (Fig. $5 \mathrm{C}$ ). A dense cellular infiltrate was interspersed among the fibrovascular stroma of the zona spongiosa, and subpopulations of cells stained strongly positive for both monocyte-macrophage and $\mathrm{T}$ cell markers. T cell infiltrates were also found in close proximity to calcium deposits intermixed with macrophages in the zona spongiosa, along valve edges, and around zones of neovascularization (Fig. $5 \mathrm{D}$ ). No cells with positive staining for $\mathrm{T}$ cell surface markers were observed at the calcification front.

$\alpha$-Actin positive smooth muscle cells were confined to the zona fibrosa, adjacent to the native valve edges, and around developing neovasculature. $\alpha$-Actin positive cells were associated with matrix protein expression and calcification, in one case of calcified healed endocarditis where valve vegetations had formed neointimal excrescences along the native valve edge (Fig. 5 E).

Immunostaining for noncollagenous bone matrix proteins revealed intense osteonectin and osteocalcin staining along the calcification front of mineralizing zones (Fig. 6, $A$ and $B$, re- 

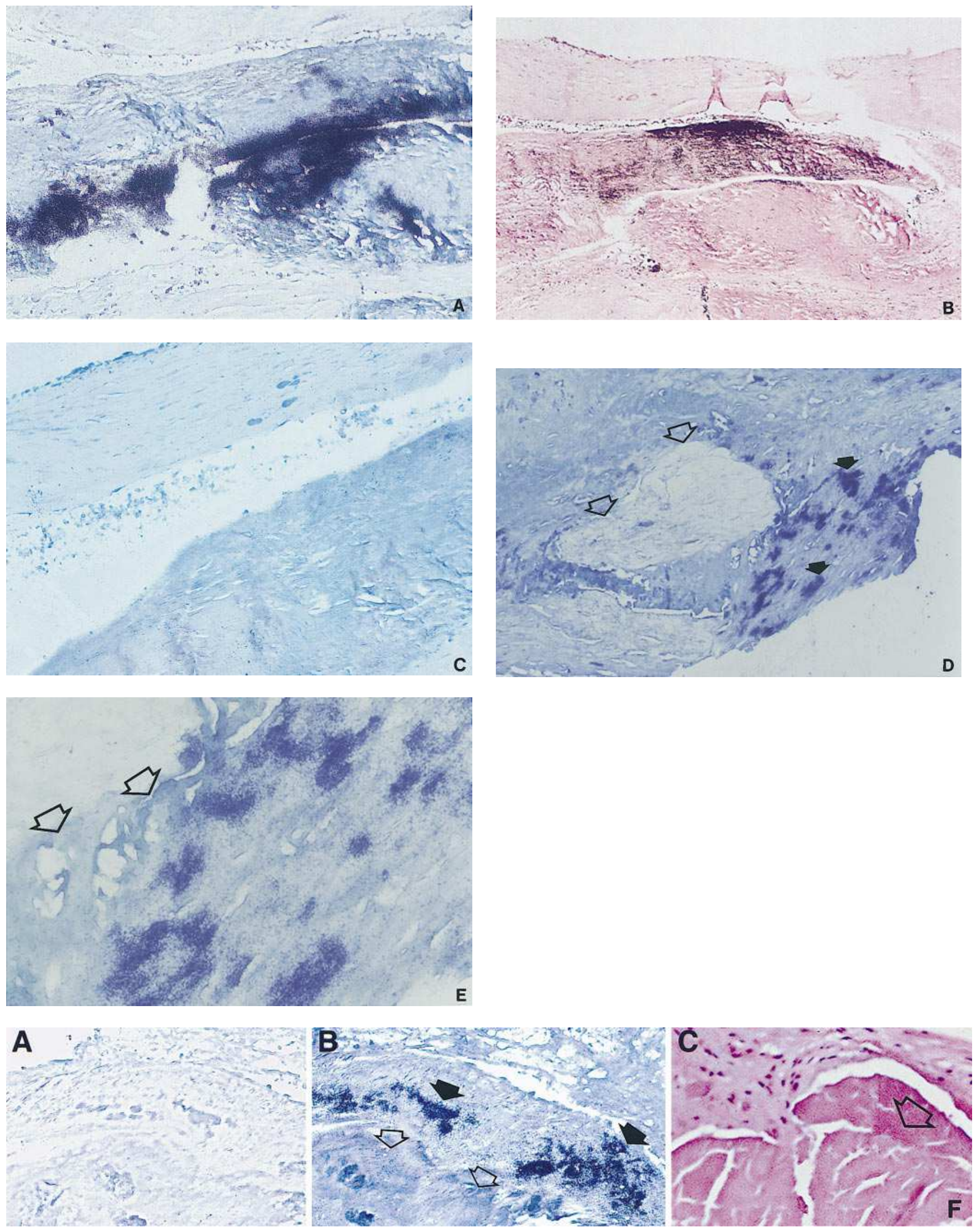

Figure 7. (A) ISH signal for osteopontin mRNA overlying cells adjacent to and within a calcified area of a porcine bioprosthetic heart valve. $(B)$ von Kossa stain of porcine bioprosthetic valve seen in $A$ showing localized calcium deposition (stained black) immediately adjacent to the cellular infiltrates expressing noncollagenous matrix mineralization-associated protein mRNA. $(C)$ Representative negative control of porcine bioprosthetic valve illustrated in $A$, using a sense probe for osteopontin, shows lack of specific ISH. $(D)$ ISH signal for osteocalcin mRNA overlying 

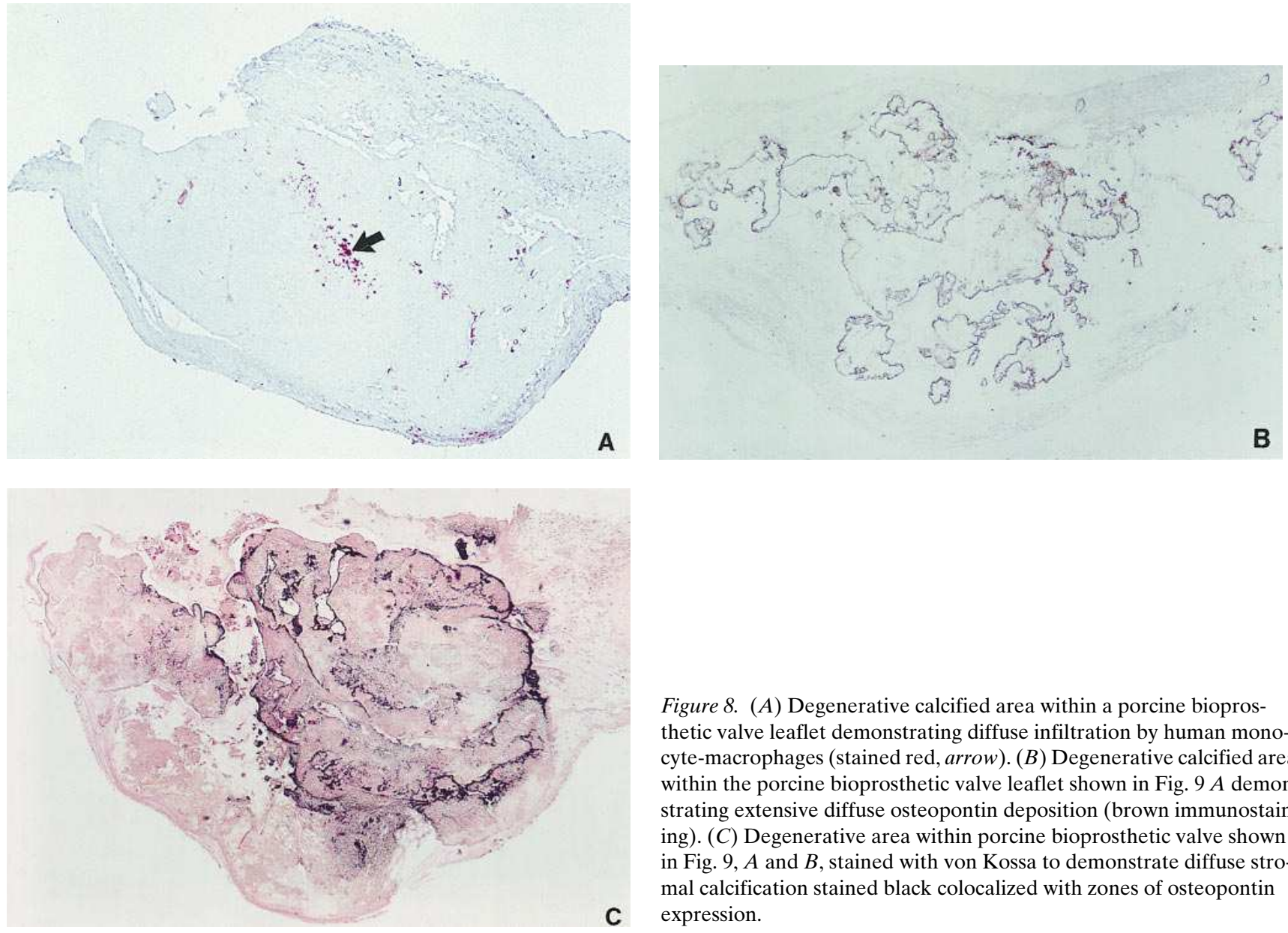

Figure 8. (A) Degenerative calcified area within a porcine bioprosthetic valve leaflet demonstrating diffuse infiltration by human monocyte-macrophages (stained red, arrow). (B) Degenerative calcified area within the porcine bioprosthetic valve leaflet shown in Fig. $9 \mathrm{~A}$ demonstrating extensive diffuse osteopontin deposition (brown immunostaining). (C) Degenerative area within porcine bioprosthetic valve shown in Fig. 9, $A$ and $B$, stained with von Kossa to demonstrate diffuse stromal calcification stained black colocalized with zones of osteopontin C expression.

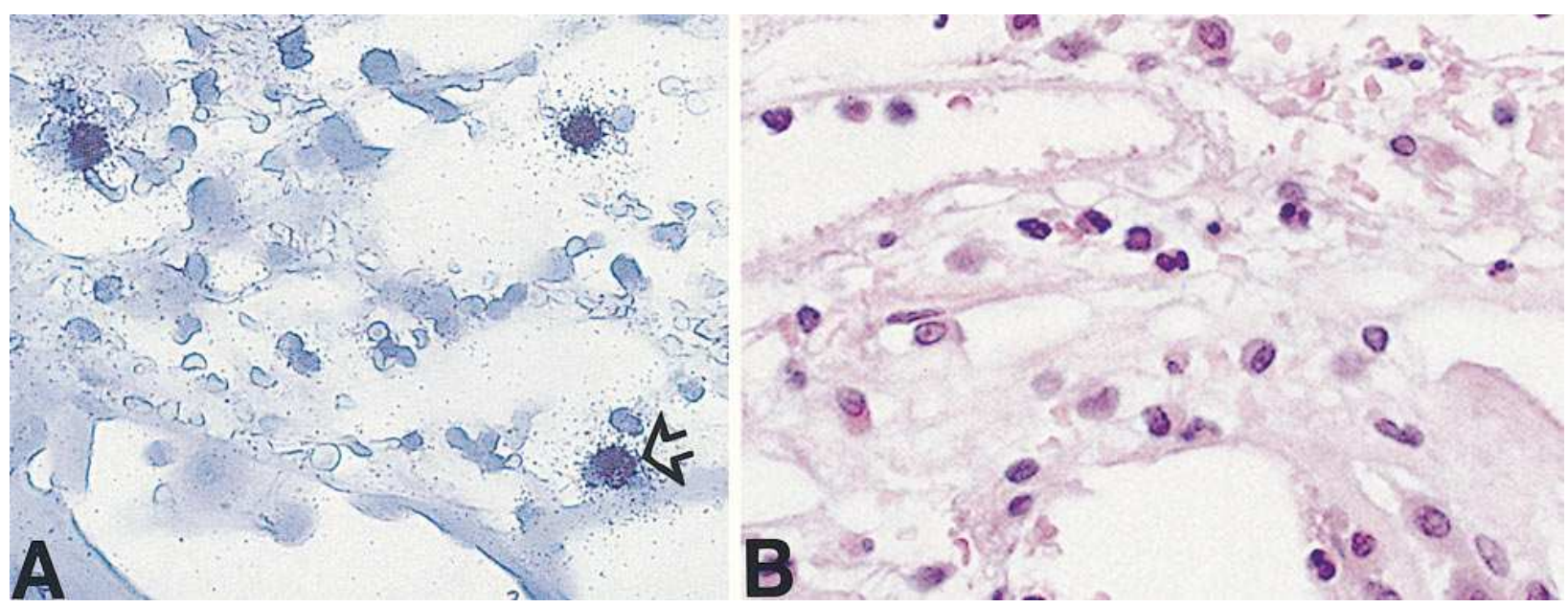

Figure 9. Degenerating but grossly noncalcified zone within the zona spongiosa of a porcine bioprosthetic valve stained with hematoxylin and eosin to demonstrate an extensive infiltrate of mononuclear (including monocyte-macrophage) cells $(B)$, some of which express noncollagenous matrix protein (osteopontin) mRNA (arrow, A).

cells (closed arrows) adjacent to a zone of nonosseous calcification (open arrows) within a native human valve. (E) High powered view of osteocalcin mRNA signal overlying cells of the native human valve and adjacent to the calcification front (open arrows) shown in $D$. ( $F$ ) ISH signal for osteonectin mRNA (closed arrows) overlying cells immediately adjacent to a zone of calcification (open arrows) within a native valve (panel $B$ ). The corresponding negative sense control is shown in panel $A$. Panel $C$ demonstrates hematoxylin and eosin staining of the cellular infiltrates surrounding the calcified valve zone (open arrow), which are expressing mRNA signal for osteonectin, shown in panel $B$. 
spectively). Strong immunoreactivity for osteonectin was observed along the calcification front and within osteocytes of newly formed woven "bone." Osteonectin was also localized to pleomorphic mesenchymal cells within the fibrovascular stroma adjacent to the mineralization front (Fig. $6 \mathrm{~A}$ ). Osteocalcin immunoreactivity was observed within osteoblast-like cells at the calcification front of mineralized zones and within the osteocytes of woven bone (Fig. $6 \mathrm{~B}$ ). Osteocalcin was not observed within the mesenchymal cells of the adjacent fibrovascular stroma. Osteopontin was diffusely distributed around and within calcified zones, as well as in cells infiltrating the fibrovascular stroma between zones of mineralization (Fig. $6 C$ ). Nonimmune serum served as a negative control (Fig. 6D).

Porcine bioprosthetic valves. Special staining with von Kossa and Goldner's-Masson-Trichrome stains for mineralized valve areas revealed diffuse calcium deposition along zones of greatest cusp flexion including the cusp attachments and commissures. Immunohistochemical and in situ hybridization revealed intense staining for osteopontin, osteocalcin, osteonectin protein, and mRNA signal adjacent to and within regions of mineralization (Figs. 7 and 8). Within degenerative calcified zones of bioprosthetic valves, diffuse CD68 positive monocyte-macrophage cell infiltration (human origin) and extensive noncollagenous matrix protein deposition was observed surrounding calcified areas (Fig. 8, $A-C$ ). Degenerating but grossly noncalcified areas within the zona spongiosa of bioprosthetic valves also exhibited a dense mononuclear inflammatory cell infiltrate associated with noncollagenous matrix mRNA expression (Fig. 9).

\section{ISH}

Strong ISH signals for osteopontin, osteocalcin, and osteonectin were visualized in close proximity to calcified and degenerative zones within both native human and porcine bioprosthetic valves. ISH signal was distinctly localized to cellular infiltrates including CD68 positive human monocyte-macrophages around zones of established calcification identified by specialized staining (Fig. 7, $A-E$ ). Noncollagenous matrix protein mRNA expression was also observed to a lesser extent in zones of valvular degeneration exhibiting minimal or no mineralization (Fig. 9). Noncollagenous matrix protein expression corresponded anatomically in all cases to the known sites of valve calcification, both at the cusp free edges and at sites of marked flexion deformity such as the basal cusp attachment and commissures. Morphologic and immunohistologic analyses of zones expressing strong matrix protein mRNA signal demonstrated monocyte-macrophage cells, T-lymphocytes, fibroblast-like mesenchymal cells, and $\alpha$-actin positive smooth muscle cells colocalized with zones of matrix protein mRNA expression and calcification. In porcine bioprosthetic valves, monocytemacrophages present in regions of strong matrix protein mRNA signal were identified as human in origin. In both native and bioprosthetic valves, mesenchymal cells morphologically similar to fibroblasts and positive for $\alpha$-smooth muscle cell actin and vimentin were associated with mRNA signal for osteocalcin, osteonectin, and osteopontin. $\mathrm{T}$ cell infiltrates were extensively intermixed in cellular regions expressing matrix protein mRNA.

All three noncollagenous proteins are normally present and expressed in a coordinated fashion in calcified bone matrix (28). For this reason, we combined the ISH scores for osteopontin, osteonectin, and osteocalcin for analysis. Comparison of averaged total matrix protein mRNA signal scores among groups demonstrated a significant difference between the native valve groups; grossly calcified native valves (group IV) contained significantly more mRNA for osteocalcin, osteonectin, and osteopontin compared with noncalcified native valves (group III) $(P=0.02)$ (Fig. 10). No significant difference in averaged total matrix protein mRNA signal was demonstrable between bioprosthetic calcified valves (group II) and native calcified valves (group IV) $(P=0.24)$. The difference in mean matrix protein mRNA signal score among the bioprosthetic noncalcified valves (group I) and bioprosthetic grossly calcified valves (group II) did not reach statistical sig-

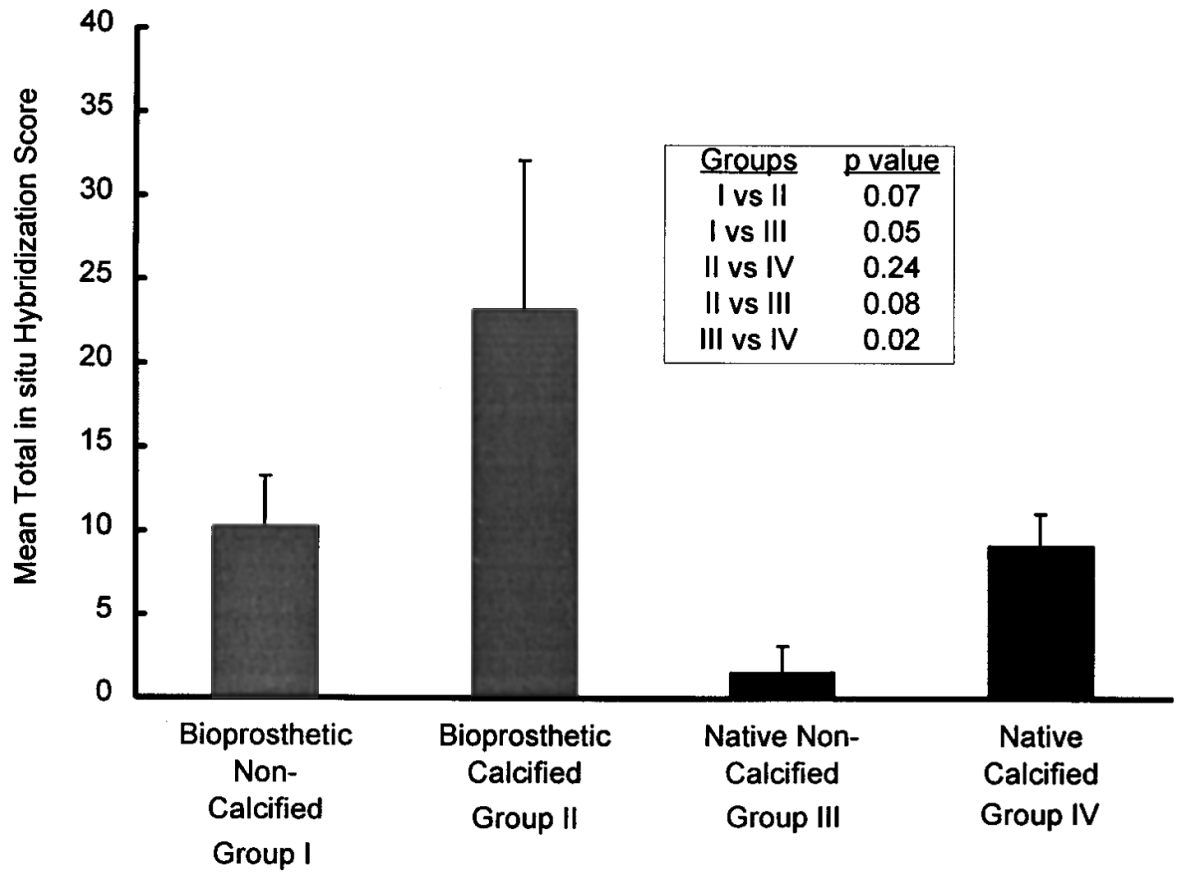

Figure 10. Total matrix protein mRNA signal score averaged for all three matrix proteins (osteopontin, osteocalcin, and osteonectin) and compared by calcification status. 
Table III. $2 \times 2$ Contingency Table Analysis of Positive Versus Negative ISH Signal Status for Matrix Proteins among Native and Bioprosthetic Valve Groups

\begin{tabular}{clc}
\hline & \multicolumn{1}{c}{ Groups compared } & $P$ value \\
\hline $\begin{array}{c}\text { Positive versus } \\
\text { negative ISH } \\
\text { signal status }\end{array}$ & $\begin{array}{l}\text { Bioprosthetic valves (I vs. II) } \\
\text { Native valves (III vs. IV) }\end{array}$ & $0.03^{*}$ \\
& $\begin{array}{c}\text { Calcified valves (bioprosthetic } \\
\text { vs. native) (II vs. IV) } \\
\text { Noncalcified valves (bioprosthetic } \\
\text { vs. native) (I vs. III) }\end{array}$ & $0.01^{*}$ \\
& & 0.49 \\
\hline
\end{tabular}

ISH signal status for each valve was defined as positive if $\geq 2$ different matrix protein probes demonstrated $>5$ positive cells/slide; negative was defined as $<2$ different matrix protein probes demonstrating $<5$ positive cells/slide. ${ }^{*} P \leq 0.05$ by Fisher's exact test.

nificance $(P=0.07)$. The noncalcified bioprosthetic valves (group I) exhibited significantly higher matrix protein mRNA signal scores compared with noncalcified native valves (group III) $(P=0.05)$. When valves were stratified according to positive versus negative ISH signal status, both calcified bioprosthetic valves $(P=0.03)$ and calcified native valves $(P=0.01)$ were significantly more positive for noncollagenous matrix protein mRNA than their noncalcified counterparts (Table III).

Comparison among native and bioprosthetic valves of mean ISH signal scores for individual matrix proteins, based on histologic calcium score (high versus low), is summarized in Table IV. Bioprosthetic valves with high calcium scores exhibited a higher mean osteonectin score than bioprosthetic valves with low calcium scores. Native valves with high calcium scores exhibited a higher mean osteocalcin score than native valves with low calcium scores. Neither of these associations reached statistical significance $(P=0.09$ for osteonectin in bioprosthetic valves and $P=0.08$ for osteocalcin in native valves).

\section{Discussion}

The present findings indicate that zones of calcification within both native and xenograft bioprosthetic heart valves are

Table IV. Summary of Mean In Situ mRNA Signal Score for Each Matrix Protein, Comparing Native and Bioprosthetic Valve Groups Separated by Histologic Calcium Score

\begin{tabular}{|c|c|c|c|c|}
\hline & \multicolumn{2}{|c|}{ Bioprosthetic } & \multicolumn{2}{|c|}{ Native } \\
\hline & $\begin{array}{l}\text { High } \mathrm{Ca}^{2+} \\
\text { score }\end{array}$ & $\begin{array}{c}\text { Low } \mathrm{Ca}^{2+} \\
\text { score }\end{array}$ & $\begin{array}{l}\text { High } \mathrm{Ca}^{2+} \\
\text { score }\end{array}$ & $\begin{array}{l}\text { Low } \mathrm{Ca}^{2+} \\
\text { score }\end{array}$ \\
\hline \multicolumn{5}{|c|}{ Mean osteocalcin } \\
\hline ISH score & $18.6 \pm 12.5$ & $15.0 \pm 5.4$ & $15.0 \pm 7.6^{*}$ & $1.0 \pm 0.6$ \\
\hline \multicolumn{5}{|c|}{ Mean osteonectin } \\
\hline ISH score & $41.2 \pm 24.2^{\ddagger}$ & $9.4 \pm 2.5$ & $6.0 \pm 3.1$ & $5.5 \pm 3.2$ \\
\hline \multicolumn{5}{|c|}{ Mean osteopontin } \\
\hline ISH score & $16.8 \pm 8.1$ & $6.0 \pm 2.9$ & $3.3 \pm 2.4$ & $7.5 \pm 5.6$ \\
\hline
\end{tabular}

Osteocalcin: $* P=0.08$ High $\mathrm{Ca}^{2+}$ vs. Low $\mathrm{Ca}^{2+}$ Native; Osteocalcin: ${ }^{\ddagger} P=$ 0.09 High $\mathrm{Ca}^{2+}$ vs. Low $\mathrm{Ca}^{2+}$ Bioprosthetic. High $=\mathrm{Ca}^{2+}$ score $>1$; Low $=\mathrm{Ca}^{2+}$ score $\leq 1$. closely associated with noncollagenous matrix protein expression by cellular components. We have demonstrated that cellular expression of noncollagenous matrix proteins that coordinate normal bone formation (osteopontin, osteocalcin, and osteonectin) occurs in close anatomic proximity to overt calcification and zones of valvular degeneration undergoing incipient mineralization. Therefore, we postulate that cellular expression of noncollagenous matrix proteins may serve a regulatory role in valve calcification. In the case of bioprosthetic and native valves, many of the cells that express noncollagenous matrix proteins in this study have been identified by immunohistochemistry as human macrophages. Our data indicate a close relationship among valvular infiltration by cellular elements (smooth muscle cells, T-lymphocytes, monocytemacrophages, and mesenchymal cells), expression of noncollagenous matrix protein, and calcification of both native human and porcine bioprosthetic heart valves. The association of local cellular expression of noncollagenous matrix proteins with valvular calcification suggests that valvular mineralization may be an actively regulated and potentially modifiable process in both valve types.

Cellular inflammatory infiltrates are not characteristic of undiseased porcine bioprosthetic or native human valve tissue. This study demonstrates prominent $T$ cell and macrophage infiltrates at sites of mRNA and protein localization for all three noncollagenous matrix proteins associated with calcification in native human and bioprosthetic valves. The presence of osteopontin is consistent with prior observations of osteopontin expression by macrophages in calcified atherosclerotic coronary arteries, and after necrotizing injury in myocardium, renal tubular interstitium, lung, skeletal tissue, and skin (32). Osteocalcin and osteopontin have chemotactic properties for monocyte-macrophage cells and may inhibit mineralization and promote resorption (32-34). Recently, HLA-DR expression has been shown to be upregulated in interstitial fibroblasts and T-lymphocytes close to zones of calcification in degenerative, stenotic aortic valves, suggesting an immune basis for this process (35). However, the definitive role of $\mathrm{T}$ cells and macrophages remains uncertain as bioprosthetic implants calcify in athymic (nude) BALBc mice and in Millipore exclusion chambers that block direct cell contact with valve tissue $(36,37)$. Focal accumulation of T-lymphocytes surrounding deposits of calcium within stenotic valves may serve as a potent source of cytokines (38). Antigenic stimulation of lymphocytes leads to enhanced expression of CD44 surface receptors and secretion of osteopontin (39). Recent data indicate that osteopontin is a ligand for CD44 (40). Thus, the interaction among osteopontin, CD44 containing lymphocytes, and monocytes may provide a mechanism to recruit inflammatory cells that modulate the calcification process within heart valves.

Monocyte-macrophages and smooth muscle cells synthesize osteopontin $(18,22,40-46)$, matrix Gla protein $(43,46)$ and osteonectin (43) in cell culture, atherosclerotic plaques $(41,42,45)$, or restenotic neointima $(22,42,47)$. Vascular pericyte-like cells $(23,48)$, monocytes $(49)$, and endothelial cells (45) also express osteopontin. Thus, a wide variety of mesenchymal and inflammatory cells synthesize the noncollagenous matrix proteins required to promote and regulate the development of mineralized matrix. The chemotactic properties of these proteins may promote further cell recruitment and continued matrix protein expression.

Prior models of bioprosthetic valve calcification have fo- 
cused on the role of mechanical damage and chemical crosslinking in disrupting cellular calcium regulation, thereby promoting intracellular calcium accumulation, calcium phosphate deposition, crystal nucleation, and growth $(1,17)$. This theory of mineralization, while concordant with the known data on cellular location of calcium phosphate deposition, does not fully explain the concurrent process of extracellular matrixassociated mineralization. Matrix proteins such as osteocalcin, osteonectin, and osteopontin may regulate calcification by actively coordinating the recruitment of cellular elements required for mineralization. Such a concept is in keeping with the idea that the mineralization of extraskeletal tissues passively termed "dystrophic mineralization" is, in fact, a coordinated cell-mediated process. There is emerging evidence that other related reparative processes such as atherosclerotic calcification and coronary restenosis also involve cell-mediated, coordinated matrix protein expression (18, 22-24, 43-48).

Studies in different species have shown that both mRNA and protein for osteopontin are closely associated with osteoblasts, osteocytes, osteoclasts, smooth muscle cells, endothelial cells, foam cells, macrophages, and pericyte-like cells around zones of calcification $(18,19,22-24,50)$. Osteopontin, also known as Eta-1, uropontin, or bone sialoprotein I, is an acidic phosphorylated glycoprotein with highly conserved regions including the cell binding motif GRGDS or Arg-Gly-Asp sequence (50). This sequence is capable of recognizing a variety of cell surface integrins including $\alpha_{v} \beta_{3}, \alpha_{v} \beta_{1}$, and $\alpha_{v} \beta_{5}$, thereby mediating the adhesion and migration of cells associated with mineralized matrix (51-53). The central region of osteopontin is highly negatively charged and binds ionic calcium with high capacity and low affinity $(34,50)$. Osteopontin has direct chemoattractive effects on smooth muscle cells, endothelial cells, and macrophages to which it binds with high affinity (5456). Osteopontin may also enhance cell motility in remodeling tissues by stimulating the production of local matrix metalloproteinase enzymes that promote matrix degradation (50). Osteopontin stimulates bone resorption in vitro by mediating adhesion and chemotaxis of osteoclasts and inhibits hydroxyapatite crystal growth $(55,57)$. Thus, osteopontin plays a major role in the regulation of the mineralization process and has inherent capabilities to enhance or inhibit the calcification process (18, $27)$. Osteopontin is present in human aortic valves and may regulate the process of calcification in this tissue (58).

Cell-associated noncollagenous matrix protein expression provides a unifying hypothesis for both intrinsic cell- and matrix-associated mineralization observed within native and bioprosthetic heart valves, as well as extrinsic calcification of the valve surface occurring within thrombotic endocarditic vegetations or fibroelastic host tissue overlying synthetic polymer heart valves. Peripheral blood platelets and bone marrow megakaryocytes produce all four major protein mRNAs associated with calcification (osteocalcin, osteonectin, osteopontin, and bone sialoprotein II), suggesting that these cells may serve an osteoblast-like role in dystrophic calcification (59). Osteonectin or SPARC (Secreted Protein, Acidic and Rich in Cysteine), a 38-kD acidic glycoprotein with high interspecies homology, has been found within the $\alpha$-granules of platelets at sites of injury such as valve leaflet surfaces where it regulates the effects of platelet-derived growth factor in wound healing (60). Platelet thrombus may serve as a concentrated source of noncollagenous matrix proteins (61). Osteonectin is one of the most abundant matrix proteins in bone and has a high affinity for calcium, type I collagen, and hydroxyapatite. Osteonectin has been proposed as the linking protein between mineral deposition and collagen and may inhibit the formation and growth of apatite crystals in vitro $(62,63)$. Enhanced osteonectin production in tissues undergoing high rates of proliferation and remodeling may also regulate cell shape, migration, differentiation, and cell cycle progression $(34,63)$. Thus, the presence of osteonectin at sites of tissue remodeling and calcification in heart valves is consistent with its known role in other tissues.

Previous reports have documented the presence of vitamin $\mathrm{K}$-dependent $\boldsymbol{\gamma}$-carboxyglutamic acid containing proteins such as osteocalcin (bone Gla protein) in different types of pathologic calcification associated with atherosclerotic plaque and native and bioprosthetic valves $(18,24,46,64-66)$. Osteocalcin is secreted by osteoblasts and exhibits high affinity for calcium, phospholipid, and hydroxyapatite (34). Osteocalcin is abundant in the extracellular matrix of mineralized tissues (26). Prior studies have demonstrated passive adsorption from the plasma, but the present data indicate that in situ expression of osteocalcin by cells within extraskeletal mineralized tissues also occurs. The presence of osteocalcin in circulating platelets (67) and plasma suggests that it may serve a role in calcification of tissue and artificial surfaces exposed to blood. Osteocalcin promotes bone resorption and is chemoattractive for peripheral blood monocytes, osteoclasts, and mesenchymal cells, suggesting an important role for this extracellular matrix protein in the formation and remodeling of mineralizing tissues $(34,68)$.

We have demonstrated that cellular expression of noncollagenous matrix mineralization regulating proteins is strongly associated with zones of calcification within native human and porcine bioprosthetic heart valves. Increased levels of noncollagenous matrix protein mRNA are observed within calcified native human and bioprosthetic valves. A close anatomic relationship is observed among noncollagenous matrix protein expression, calcification, and cellular infiltration of native and bioprosthetic heart valves.

Based on these observations, we propose a common role for these noncollagenous matrix proteins in the mineralization process in bioprosthetic and native valves. In this model, matrix vesicles derived from mechanically damaged or chemically cross-linked cell membranes found in both native and prosthetic valves may serve as the initial nidus for hydroxyapatite crystal formation. Expression of osteopontin by valve cells including macrophages and T-lymphocytes may serve as an adhesion molecule for hydroxyapatite and as an adhesion/migration substrate for cells involved in mineralization. Both permissive and restrictive effects on crystal formation may be exerted by osteopontin, while osteocalcin and osteonectin may serve to regulate crystal growth and mineral resorption. Thus, local cell-associated upregulation of matrix proteins that regulate mineralization offers a unifying hypothesis for the calcification of native human and glutaraldehyde-treated porcine bioprosthetic heart valves. This mechanism is analogous to physiologic mineralization process in bone and suggests that valvular calcification is, in fact, a coordinated and potentially modifiable process associated with inflammatory cells. An improved understanding of this process may offer an effective therapeutic approach to the inhibition of native and bioprosthetic valve calcification and failure, which has thus far eluded definitive treatment. 


\section{Acknowledgments}

We thank Ms. Nicole Henry for expert preparation of the manuscript and Dr. Candace Ritchie for technical assistance and helpful discussion of the data. We are also indebted to Dr. Larry Fisher (NIDR, $\mathrm{NIH}$, Bethesda, MD) for the generous gift of antibodies LF-7, LF-32, and LF-BON-II.

This work was supported in part by Public Health Service grant NHLB 51736 and by an American College of Cardiology Merck Research Fellowship (S.S. Srivatsa).

\section{References}

1. Schoen, F.J., R.J. Levy, and H.R. Piehler. 1992. Pathological considerations in replacement heart valves. Cardiovasc. Pathol. 1:29-52.

2. O'Keefe, J.H., C.J. Lavie, R.A. Nishimura, and W.D. Edwards. 1991. Degenerative aortic stenosis. Postgrad. Med. 89:143-154.

3. Roberts, W.C. 1977. The congenitally bicuspid aortic valve. A study of 85 autopsy cases. Am. J. Cardiol. 26:72-83.

4. Sell, S., and R.E. Scully. 1965. Aging changes in the aortic and mitral valves. Histologic and histochemical studies, with observations on the pathogenesis of calcific aortic stenosis and calcification of the mitral annulus. Am. J. Pathol. 46:345-355.

5. Mills, P., G. Leech, M. Davies, and A. Leatham. 1978. The natural history of the non-stenotic aortic valve. Br. Heart J. 40:951-957.

6. Kim, K.M., J.M. Valigorsky, W.J. Mergner, R.T. Jones, R.F. Pendergrass, and B.F. Trump. 1976. Aging changes in the human aortic valve in relation to dystrophic calcification. Hum. Pathol. 7:47-60.

7. Schoen, F.J., H. Harasaki, K.M. Kim, H.C. Anderson, and R.J. Levy. 1988. Biomaterial associated calcification: pathology, mechanisms, and strategies for prevention. J. Biomed. Mater. Res. 22(Suppl. A1):11-36.

8. Schoen, F.J., and C.E. Hobson. 1985. Anatomic analysis of removed prosthetic heart valves: causes of failure of 33 mechanical valves and 58 bioprostheses 1980-1983. Hum. Pathol. 16:549-559.

9. Schoen, F.J., J. Kujovitch, R.J. Levy, and M.S. Sutton. 1988. Bioprosthetic valve failure. Cardiovasc. Clin. 18:289-317.

10. Schoen, F.J. 1987. Cardiac valve prostheses: review of clinical status and contemporary biomaterials issues. J. Biomed. Mater. Res. 21(Suppl. A1):91117 .

11. Pernmanyer-Miralda, G., J. Soler-Soler, J.M. Casan-Cava, and M.P. Tornos-Mas. 1980. Medium term fate of dura mater valvular bioprostheses. Eur. Heart J. 1:195-199.

12. Allen, D.J., G.J. Highison, L.J. Didio, E.J. Zerbini, and L.B. Puig. 1982. Evidence of remodeling in dura mater cardiac valves. J. Thorac. Cardiovasc. Surg. 84:267-281.

13. Schoen, F.J. 1987. Cardiac valve prostheses. Pathologic and bioengineering considerations. J. Cardiac Surg. 2:65-108.

14. Hilbert, S.L., V.J. Ferrans, Y. Tomita, E.E. Eidbo, and M. Jones. 1987. Evaluation of explanted polyurethane trileaflet cardiac valve prostheses. $J$. Thorac. Cardiovasc. Surg. 94:419-429.

15. Harasaki, H., J. McMahon, T. Richards, J. Goldcamp, R. Kiraly, and Y. Nose. 1985. Calcification in cardiovascular implants: degraded cell related phenomena. Trans. Am. Soc. Artif. Intern. Org. 31:489-494.

16. Glimcher, M.J. 1981. On the form and function of bone: from molecules to organs. Wolff's law revisited. In The Chemistry and Biology of Mineralized Connective Tissues. A. Veis, editor. Elsevier/North-Holland, Amsterdam. 617.

17. Levy, R.J., F.J. Schoen, J.T. Levy, A.C. Nelson, S.L. Howard, and L.J. Oshry. 1983. Biologic determinants of dystrophic calcification and osteocalcin deposition in glutaraldehyde preserved porcine aortic valve leaflets implanted subcutaneously in rats. Am. J. Pathol. 113:143-155.

18. Fitzpatrick, L.A., A. Severson, W.D. Edwards, and R.T. Ingram. 1994. Diffuse calcification associated with noncollagenous matrix protein expression in human atherosclerotic coronary arteries. Implication for the formation of calcified plaque. J. Clin. Invest. 94:1597-1604.

19. Ikeda, T., T. Shirasawa, Y. Esaki, S. Yoshiki, and K. Hirokawa. 1993. Osteopontin mRNA is expressed by smooth muscle derived foam cells in human atherosclerotic lesions of the aorta. J. Clin. Invest. 92:2814-2820.

20. Robey, P.G., N.S. Fedarko, T.E. Hefferan, P. Bianco, U.K. Vetter, W. Grzesik, A. Friedenstein, G. Van Der Pluijm, K.P. Mintz, M.F. Young, et al. 1993. Structure and molecular regulation of bone matrix proteins. J. Bone Miner. Res. 8:S483-S487.

21. Takano-Yamamoto, T., T. Takemura, Y. Kitamura, and S. Nomura. 1994. Site specific expression of mRNA's for osteonectin, osteocalcin, and osteopontin revealed by in situ hybridization in rat periodontal ligament during physiologic tooth. J. Histochem. Cytochem. 42:885-896.

22. Giachelli, C.M., N. Bae, M. Almeida, D.T. Denhardt, C.E. Alpers, and S.M. Schwartz. 1993. Osteopontin is elevated during neointima formation in rat arteries and is a novel component of human atherosclerotic plaques. J. Clin. Invest. 92:1686-1696.
23. Böstrom, K., K.E. Watson, S. Horn, C. Wortham, I.M. Herman, and L.L. Demer. 1993. Bone morphogenetic protein expression in human atherosclerotic lesions. J. Clin. Invest. 91:1800-1809.

24. Demer, L. 1995. A skeleton in the atherosclerosis closet. Circulation. 92: 2029-2032.

25. Kim, K.M. 1976. Calcification of matrix vesicles in human aortic valve and aortic media. Fed. Proc. 35:156-162.

26. Ingram, R.T., Y.K. Park, B.T. Clarke, and L.A. Fitzpatrick. 1994. Ageand gender-related changes in the distribution of osteocalcin in the extracellular matrix of normal bone and female bone. Possible involvement of osteocalcin in bone remodeling. J. Clin. Invest. 93:989-997.

27. Ingram, R.T., B.T. Clarke, L.W. Fisher, and L.A. Fitzpatrick. 1993. Distribution of noncollagenous proteins in the matrix of adult human bone: evidence of anatomic and functional heterogeneity. J. Bone Miner. Res. 8:10191029.

28. Stein, G., and J. Lian. 1993. Molecular mechanisms mediating proliferation/differentiation interrelationships during progressive development of the osteoblast phenotype. Endocr. Rev. 14:424-442.

29. Bosse, A., P. Wuisman, D.B. Jones, and K. Schwarz. 1993. Noncollagenous proteins in heterotopic ossification. Immunohistochemical analysis in 15 paraplegics. Acta Orthop. Scand. 64:634-638.

30. Fisher, L.W., J.T. Stubbs III, and M.F. Young. 1995. Antisera and cDNA probes to human and certain animal model bone matrix noncollagenous proteins. Acta Orthop. Scand. 66(Suppl. 266):61-65.

31. McKee, M.D., A. Nanci, W.J. Landis, Y. Gotoh, L.C. Gerstenfeld, and M.J. Glimcher. 1991. Effects of fixation and demineralization on the retention of bone phosphoprotein and other matrix components as evaluated by biochemical analyses and quantitative immunocytochemistry. J. Bone Miner. Res. 6:937-945.

32. Giachelli, C.M., L. Liaw, C.E. Murry, S.M. Schwartz, and M. Almeida. 1995. Osteopontin expression in cardiovascular diseases. Ann. NY Acad. Sci. 760:109-126.

33. Price. P.A. 1985. Vitamin K-dependent formation of bone Gla protein (osteocalcin) and its function. Vitam. Horm. 42:65-107.

34. Roach, H.I. 1994. Why does bone matrix contain noncollagenous proteins? The possible roles of osteocalcin, osteonectin, osteopontin, and bone sialoprotein in bone mineralization and resorption. Cell Biol. Int. 18:617-628.

35. Olsson, M., M. Rosenqvist, and J. Nilsson. 1994. Expression of HLADR antigen and smooth muscle cell differentiation markers by valvular fibroblasts in degenerative aortic stenosis. J. Am. Coll. Cardiol. 24:1664-1671.

36. Levy, R.J., F.J. Schoen, and S.L. Howard. 1983. Mechanism of calcification of porcine bioprosthetic aortic valve cusps: role of T-lymphocytes. Am. J. Cardiol. 52:629-631.

37. Dahm, M., W.D. Lyman, A.B. Schwell, S.M. Factor, and R.W. Frater. 1990. Immunogenicity of glutaraldehyde-tanned bovine pericardium. J. Thorac. Cardiovasc. Surg. 99:1082-1090.

38. Olsson, M., C.-J. Dalsgaard, A. Haegerstrand, M. Rosenqvist, L. Ryden, and J. Nilsson. 1994. Accumulation of T lymphocytes and expression of interleukin-2 receptors in nonrheumatic stenotic aortic valves. J. Am. Coll. Cardiol. 23:1162-1170

39. Patarca, R., R.A. Saavedra, and H. Cantor. 1993. Molecular and cellular basis of genetic resistance to bacterial infection: the role of the early T-lymphocyte activation-1/osteopontin gene. Crit. Rev. Immunol. 13:225-246.

40. Weber, G.F., S. Ashkar, M.J. Glimcher, and H. Cantor. 1996. Receptorligand interaction between CD44 and osteopontin (Eta-1). Science (Wash. DC). 271:509-512.

41. Hirota, S., M. Imakita, K. Kohri, A. Ito, E. Morii, S. Adachi, H.M. Kim, Y. Kitamura, C. Yutani, and S. Nomura. 1993. Expression of osteopontin messenger mRNA by macrophages in atherosclerotic plaques. A possible association with calcification. Am. J. Pathol. 143:1003-1008.

42. O'Brien, E.R., M.R. Garvin, D.K. Stewart, T. Hinohara, J.B. Simpson, S.M. Schwartz, and C.M. Giachelli. 1994. Osteopontin is synthesized by macrophage, smooth muscle, and endothelial cells in primary and restenotic human coronary atherosclerotic plaques. Arterioscler. Thromb. 14:1648-1656.

43. Severson, A.R., R.T. Ingram, and L.A. Fitzpatrick. 1995. Matrix proteins associated with bone calcification are present in human vascular smooth muscle cells grown in vitro. In Vitro Cell. Dev. Biol. Animal. 31:853-857.

44. Gadeau, A., M. Campan, D. Millet, T. Candresse, and C. Desgranges. 1993. Osteopontin overexpression is associated with arterial smooth muscle cell proliferation in-vitro. Arterioscler. Thromb. 13:120-125.

45. O’Brien, E.R., M.R. Garvin, D.K. Stewart, T. Hinohara, J.B. Simpson, S.M. Schwartz, and C.M. Giachelli. 1994. Osteopontin is synthesized by macrophage, smooth muscle and endothelial cells in primary and restenotic human coronary atherosclerotic plaques. Arterioscler. Thromb. 14:1648-1656.

46. Shanahan, C.M., R.B. Cary, J.C. Metcalfe, and P. Weissberg. 1994. High expression of genes for calcification-regulating proteins in human atherosclerotic plaques. J. Clin. Invest. 93:2393-2402.

47. Srivatsa, S.S., R.S. Schwartz, D.R. Holmes, Jr., W.D. Edwards, Y.-K. Park, and L.A. Fitzpatrick. 1994. Coronary artery injury markedly upregulates matrix protein mRNA following experimental balloon angioplasty. Clin. Res. 42:180a. (Abstr.)

48. Watson, K.E., K. Bostrom, R. Ravindranath, T. Lam, B. Norton, and 
L.L. Demer. 1994. TGF- $\beta 1$ and 25-hydroxycholesterol stimulate osteoblast-like vascular cells to calcify. J. Clin. Invest. 93:2106-2113.

49. Miyazaki, Y., M. Setoguchi, S. Yoshida, Y. Higuchi, S. Akizuki, and S. Yamamoto. 1990. The mouse osteopontin gene: expression in monocytic lineages and complete nucleotide sequences. J. Biol. Chem. 265:14432-14438.

50. Denhardt, D.T., and X. Guo. 1993. Osteopontin: a protein with diverse functions. FASEB (Fed. Am. Soc. Exp. Biol.) J. 7:1475-1482.

51. Liaw, L., V. Lindner, S.M. Schwartz, A.F. Chambers, and C.M. Giachelli. 1995. Osteopontin and $\beta_{3}$ integrin are coordinately expressed in regenerating endothelium in vivo and stimulate Arg-Gly-Asp-dependent endothelial migration in vitro. Circ. Res. 77:665-672.

52. Liaw, L., M.P. Skinner, E.W. Raines, R. Ross, D.A. Cheresh, S.M. Schwartz, and C.M. Giachelli. 1995. The adhesive and migratory effects of osteopontin are mediated via distinct cell surface integrins. J. Clin. Invest. 95:713724.

53. Hu, D.D., E.C. Lin, N.L. Kovach, J.R. Hoyer, and J.W. Smith. 1995. A biochemical characterization of the binding of osteopontin to integrins alpha $\mathrm{v}$ beta 1 and alpha v beta 5. J. Biol. Chem. 270:26232-26238.

54. Singh, R.P., R. Patarca, J. Schwartz, P. Singh, and H. Cantor. 1990. Definition of a specific interaction between the early $T$ lymphocyte activation-1 (Eta-1) protein and murine macrophages in vitro and its effects upon macrophages in vivo. J. Exp. Med. 181:1931-1942.

55. Giachelli, C.M., S.M. Schwartz, and L. Liaw. 1995. Molecular and cellular biology of osteopontin. Potential role in cardiovascular disease. Trends Cardiovasc. Med. 5:88-95.

56. Liaw, L., M. Almeida, C. Hart, S.M. Schwartz, and C.M. Giachelli. 1994. Osteopontin promotes vascular cell adhesion and spreading and is chemotactic for smooth muscle cells in vitro. Circ. Res. 74:214-224.

57. Ross, F.P., J. Chappel, J.I. Allvarez, D. Sander, W.T. Butler, M.C. Farach-Carson, K.A. Mintz, P.G. Robey, S.L. Teitelbaum, and D.A. Cheresh. 1993. Interaction between the bone matrix proteins osteopontin and bone sialoprotein and the osteoclast integrin $\alpha_{\mathrm{v}} \beta_{3}$ potentiate bone resorption. J. Biol. Chem. 268:9901-9907.

58. O’Brien, K.D., J. Kuusisto, D.D. Reichenbach, M. Ferguson, C. Giachelli, C.E. Alpers, and C.M. Otto. 1995. Osteopontin is expressed in human aortic valvular lesions. Circulation. 92:2163-2168.

59. Thiede, M.A., S.L. Smock, D.N. Peterson, W.A. Grasser, D.D. Thompson, and S.K. Nishimoto. 1994. Presence of messenger ribonucleic acid encoding osteocalcin, a marker of bone turnover, in bone marrow megakaryocytes and peripheral blood platelets. Endocrinology. 135:929-937.

60. Stenner, D.D., R.P. Tracy, B.L. Riggs, and K.G. Mann. 1985. Human platelets contain and secrete osteonectin, a major protein of mineralized bone. Proc. Natl. Acad. Sci. USA. 82:2267-2271.

61. Raines, E.W., T.F. Lane, M.L. Iruela-Arispe, R. Ross, and E.H. Sage. 1992. The extracellular glycoprotein SPARC interacts with platelet-derived growth factor (PDGF)-AB and -BB and inhibits the binding of PDGF to its receptors. Proc. Natl. Acad. Sci. USA. 89:1281-1285.

62. Jundt, G., K.H. Berghauser, J.D. Termine, and A. Schulz. 1987. Osteonectin: a differentiation marker of bone cells. Cell. Tissue Res. 248:409-415.

63. Tremble, P.M., T.F. Lane, E.H. Sage, and Z. Werb. 1993. SPARC, a secreted protein associated with morphogenesis and tissue remodeling, induces expression of metalloproteinase in fibroblasts through a novel extracellular matrix dependent pathway. J. Cell Biol. 121:1433-1444.

64. Levy, R.J., J.A. Zenker, and W.F. Benhard. 1983. Porcine bioprosthetic valve calcification in bovine left ventricle-aorta shunts: studies of the deposition of vitamin K-dependent proteins. Ann. Thorac. Surg. 36:187-192.

65. Levy, R.J., C. Gundberg, and R. Scheinman. 1983. The identification of the vitamin $\mathrm{K}$ dependent bone protein osteocalcin as one of the $\gamma$-carboxyglutamic acid containing proteins present in calcified atherosclerotic plaque and mineralized heart valves. Atherosclerosis. 46:49-56.

66. Levy, R.J., J.A. Zenker, and J.B. Lian. 1980. Vitamin K-dependent calcium binding proteins in aortic valve calcification. J. Clin. Invest. 65:563-566.

67. Thiede, M.A., S.L. Smock, D.N. Petersen, W.A. Grasser, D.D. Thompson, and S.K. Nishimoto. 1994. Presence of messenger ribonucleic acid encoding osteocalcin, a marker of bone turnover, in bone marrow megakaryocytes and peripheral blood platelets. Endocrinology. 135:929-937.

68. Glowacki, J., and J.B. Lian. 1987. Impaired recruitment and differentiation of osteoclast progenitors by osteocalcin-deplete bone implants. Cell Differ. 21:247-254 